\title{
BIODIVERSITY OBSERVATIONS
}

RESEARCH PAPER (SITE REPORT)

\section{The birds of Fort Fordyce Reserve, Eastern Cape}

Author(s):

Craig AJFK, and Hulley PE
Journal editor:

Pete Laver

Manuscript editor:

Pete Laver

Received: November 19, 2018; Accepted: February 2, 2020; Published: February 02, 2020

\section{Citation: Craig AJFK, and Hulley PE. 2020. The birds of Fort Fordyce Reserve, Eastern Cape. Biodiversity Observations 11.1:1-16}

Journal: https:/ /journals.uct.ac.za/index.php/BO/

Manuscript: https://journals.uct.ac.za/index.php/BO/article/view/687

PDF: https://journals.uct.ac.za/index.php/BO/article/view/687/657

HTML: http:/ / thebdi.org/blog/2020/02/02/birds-of-fort-fordyce-reserve
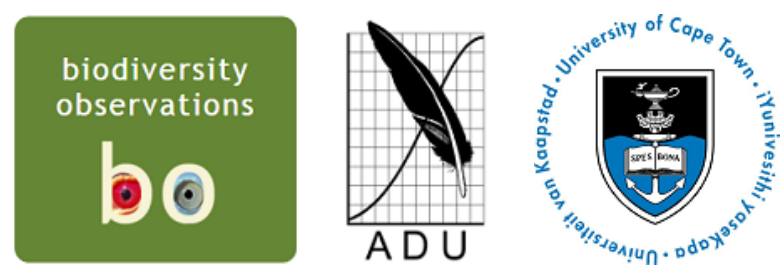

Biodiversity Observations is an open access electronic journal published by the Animal Demography

Unit at the University of Cape Town, available at https://journals.uct.ac.za/index.php/BO/

The scope of Biodiversity Observations includes papers describing observations about biodiversity in general, including animals, plants, algae and fungi. This includes observations of behaviour, breeding and flowering patterns, distributions and range extensions, foraging, food, movement, measurements, habitat and colouration/plumage variations. Biotic interactions such as pollination, fruit dispersal, herbivory and predation fall within the scope, as well as the use of indigenous and exotic species by humans. Observations of naturalised plants and animals will also be considered. Biodiversity Observations will also publish a variety of other interesting or relevant biodiversity material: reports of projects and conferences, annotated checklists for a site or region, specialist bibliographies, book reviews and any other appropriate material. Further details and guidelines to authors are on the journal website (https://journals.uct.ac.za/index.php/BO/). 


\title{
The birds of Fort Fordyce Reserve, Eastern Cape
}

\author{
Adrian JFK Craig Department of Zoology \& Entomology, Rhodes University, Grahamstown, 6140, South \\ Africa \\ Patrick E Hulley Department of Zoology \& Entomology, Rhodes University, Grahamstown, 6140, South \\ Africa
}

Since 2007 we have carried out surveys of birds at Fort Fordyce, including mist-netting. To date, 175 species have been recorded, including 9 Red Data species, of which one is a breeding resident, and three others may be breeding in the reserve. There are 56 species typical of montane forest; most are present throughout the year. With $>500$ birds ringed and 50 recaptures, the oldest records to date are 8 years for an olive thrush and a black-backed puffback.

\section{Introduction}

Forest is a rare habitat in South Africa, covering $<1 \%$ of the land surface, and it is currently much fragmented. However, there are very few areas which were covered by extensive tracts of natural forest even before human-induced changes to the original vegetation distribution (Rutherford and Westfall 1986). Many small forest remnants, originally under the control of the Department of Forestry, have subsequently been transferred to state conservation departments.

Fort Fordyce (Figure 1) was previously a hilltop forestry station, with extensive plantations of alien pine and eucalypt trees, while indigenous forest persisted on the steeper slopes. In 1987 it became a nature reserve administered by the Cape Provincial Department of Nature Conservation, and removal of alien vegetation began. Most of the plantations have now been felled, but secondary infestations of black wattle (Acacia mearnsii) cover significant areas, although there is also extensive regeneration of natural vegetation. This protected area covers 2155 hectares, and with the Mpofu Game Reserve (7500 hectares) in the adjacent valley, is currently managed by Eastern Cape Parks; these two reserves form part of the Amatola-Katberg Mountain Important Bird Area (BirdLife South Africa 2015).

Biodiversity Observations is an open access electronic journal published by the Animal Demography Unit at the University of Cape Town, available at https://journals.uct.ac.za/index.php/BO/. A permanent link for an online version of this manuscript can be found at https://journals.uct.ac.za/index.php/BO/article/view/687, which includes the PDF: https://journals.uct.ac.za/index.php/BO/article/view/687/657. An HTML version can be found at http:/ / thebdi.org/blog/2020/02/02/birds-of-fort-fordyce-reserve.

Journal editor: Pete Laver; Manuscript editor: Pete Laver; Corresponding author: a.craig@ru.ac.za

Received: November 19, 2018; Accepted: February 2, 2020; Published: February 02, 2020

Recommended citation: Craig AJFK, and Hulley PE. 2020. The birds of Fort Fordyce Reserve, Eastern Cape. Biodiversity Observations 11.1:1-16

Manuscript subject: Site report 


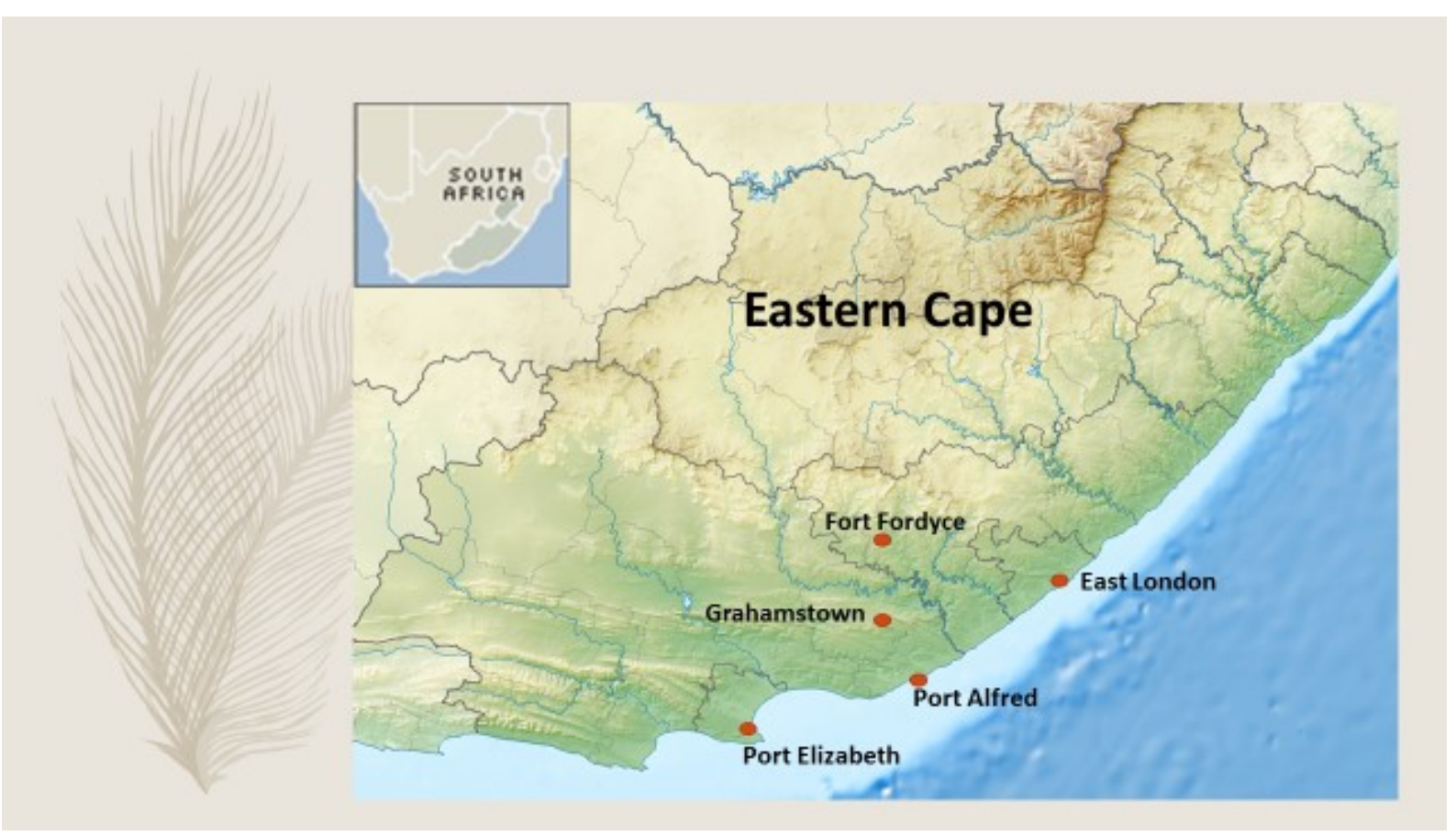

Figure 1: Location of Fort Fordyce in South Africa

The plateau at Fort Fordyce (altitude $1400 \mathrm{~m}$ ) has areas of open grassland where grazing mammals have been introduced (black wildebeest Connochaetes gnou, Burchell's zebra Equus quagga burchellii, red hartebeest Alcelaphus buselaphus caama). Bushbuck (Tragelaphus sylvaticus) and blue duiker (Philantomba monticola) occur naturally in the forested areas; baboon (Papio ursinus) and vervet monkey (Chlorocebus pygerythrus) are present, but no samango monkeys (Cercopithecus albogularis) have been recorded. Caracal (Caracal caracal) is the largest resident predator. Annual rainfall averages $1125 \mathrm{~mm}$ (mean over 15 years); summer maximum temperatures range to $42^{\circ} \mathrm{C}$ while frost occurs regularly in winter, and snow has been recorded in some years.

Based on surveys of the avifauna since 2007 (Craig 2007, 2012) we have posed the following questions:

1. Does this patch of Afromontane forest preserve a significant component of forest birds, particularly endemic species, and species of conservation concern?

2. Are these birds resident throughout the year, or is there evidence for seasonal movements?

\section{Methods}

Since May 2007, we have visited Fort Fordyce on 47 occasions, mostly single day visits. On each occasion, at least two observers have followed a regular route within the forest and across the grassland area, recording all birds seen and heard. These data have been submitted to the Southern African Bird Atlas Project (SABAP2). We have also set approximately $100 \mathrm{~m}$ of mist nets along a track near the reserve office and chalets (Figure 2). 


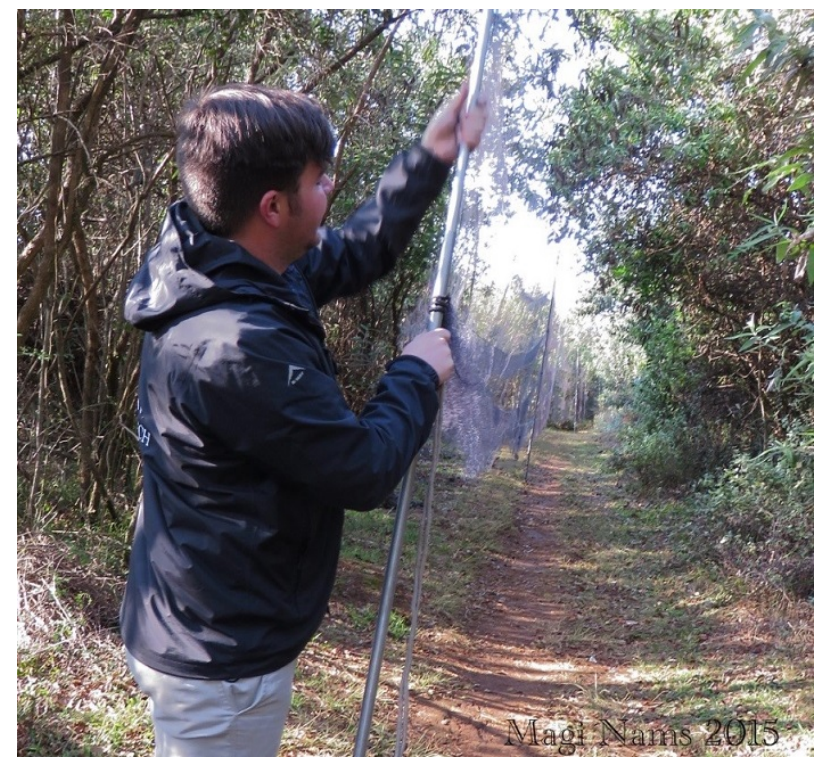

Figure 2: Mist net line at Fort Fordyce (Photo Magi Nams)

The vegetation here is regenerating scrub-forest, with a small patch of pine trees remaining to the east of the net line. All birds captured have been ringed with standard metal rings issued by SAFRING. Apart from our own data, there are 10 surveys by other observers submitted to SABAP2, and three checklists in the Birds in Reserves Project (BIRP). The reserve straddles two pentads (the $5^{\prime} \times 5^{\prime}$ minute map units used for SABAP2), including the NW corner of pentad 3240_2630 and the NE sector of pentad 3240_2625 (SABAP2, accessed 13 December 2017). However, virtually all data collection has been within the map unit 3240_2625.

Prior to 2007, we visited the reserve on three occasions (September 1988, April 1989, August 1997) during student field trips lasting 3 days each. Birds were mist-netted, and species lists recorded for each visit; these data are discussed separately. Data are also available from the first bird atlas (SABAP1, Harrison et al. 1997), but the mapping unit at that time was a "quarter degree square" $\left(15^{\prime} \times 15^{\prime}\right)$, which covers a larger area than the reserve and thus incorporated the valley with dry thornveld vegetation. This is evident from the species list, which includes many taxa which have not been recorded subsequently when surveys were restricted to the forest and grassland areas within the reserve.

\section{Results and Discussion}

\section{Avifauna}

The SABAP1 list for the quarter degree square (map code 3226CB) incorporating Fort Fordyce Reserve has 211 species, but as noted above some of these are clearly birds of the low thornveld areas at the base of the pass which leads up to the plateau. Nevertheless all 86 species noted by AJFKC and PEH in the years 1988-1997 are included in the SABAP1 tally. The current list for the pentad 3240_2625, based on SABAP2, our surveys and mist-netting records, and the few additional BIRP data, is 175 species (Appendix 1); 18 of these species were not recorded during SABAP1. Three species recorded in the forest/grassland habitats in the period 19881997 have not been reported in this sector since then: spotted eagle-owl (Bubo africanus), longbilled pipit (Anthus similis) and golden-breasted bunting (Emberiza flaviventris). Of these, only the owl may be present regularly, since with few overnight stays, nocturnal birds are certainly under-reported; the other two species are likely to be occasional vagrants. For comparison, in three KwaZulu-Natal Afromontane forest reserves, Symes et al. (2002) recorded a total of 136 
species, with no more than 110 species at any one site. However, these surveys extended over only 2-4 years at their study sites.

\section{Species of conservation concern}

Table 1 lists those species recorded at Fort Fordyce, which feature in the most recent "Red Data Book" for southern Africa (Taylor et al. 2015). The frequency with which these species have been recorded (cf. Appendix 1) suggests that most are only occasional visitors to the reserve. The endangered Cape parrot (Poicephalus robustus) has roosted here occasionally, but the large flocks seen feeding on pecan nuts on farms in the valley at certain seasons fly east in the direction of the Hogsback forests each evening (pers. obs.). Only the Knysna woodpecker (Campethera notata) is a confirmed breeding resident; the African crowned eagle (Stephanoaetus coronatus) probably also nests within the protected area, and the lanner falcon (Falco biarmicus) and bush blackcap (Lioptilus nigricapillus) may do so. There are historical records of southern ground hornbill (Bucorvus leadbeateri) from this site, but none within the past 50 years.

Table 1: Conservation status of Red Data species at Fort Fordyce

\begin{tabular}{llll}
\hline Common name & Scientific name & Red data status & Status in reserve \\
\hline Cape parrot & Poicephalus robustus & Endangered & Occasional visitor \\
blue crane & Anthropoides paradiseus & Near-threatened & Occasional visitor \\
Knysna woodpecker & Campethera notata & Near-threatened & Breeding resident \\
striped flufftail & Sarothrura affinis & Vulnerable & Occasional visitor \\
Verreaux's eagle & Aquila verreauxi & Vulnerable & Occasional visitor \\
African crowned eagle & Stephanoaetus coronatus & Vulnerable & Probable breeding resident \\
secretarybird & Sagittarius serpentarius & Vulnerable & Occasional visitor \\
lanner falcon & Falco biarmicus & Vulnerable & Possible breeding resident \\
bush blackcap & Lioptilus nigricapillus & Vulnerable & Possible breeding resident \\
\hline
\end{tabular}

\section{Forest birds}

The forest bird species in Table 2 are based on Skead (1967), who listed 74 species which occur in forest in the Eastern Cape, including riverine forest. However, of the species on his list, some do not extend as far west as the Kei River (e.g. eastern bronze-naped pigeon Columba delegorguei) or are restricted to coastal forests (e.g. red-capped robin-chat Cossypha natalensis), but we have included Barratt's warbler (Bradypterus barratti) which he described as found "in scrub adjacent to forests" (Skead 1967 p. 81).

Table 2: Eastern Cape forest birds found at Fort Fordyce 2007-2017. E = endemic to southern Africa

\begin{tabular}{lll}
\hline Common name & Scientific name & Status in reserve \\
\hline long-crested eagle & Lophaetus occipitalis & Resident \\
African crowned eagle & Stephanoaetus coronatus & Resident \\
forest buzzard & Buteo trizonatus & E Probable resident \\
rufous-breasted sparrowhawk & Accipiter rufiventris & Visitor \\
African goshawk & Accipiter tachiro & Resident \\
African harrier-hawk & Polyboroides typus & Resident \\
red-necked spurfowl & Pternistis afer & Resident \\
buff-spotted flufftail & Sarothrura elegans & Visitor
\end{tabular}


Table 2: (continued)

\begin{tabular}{|c|c|c|}
\hline Common name & Scientific name & Status in reserve \\
\hline African olive pigeon & Columba arquatrix & Resident \\
\hline red-eyed dove & Streptopelia semitorquata & Resident \\
\hline tambourine dove & Turtur tympanistria & Probable resident \\
\hline lemon dove & Columba larvata & Resident \\
\hline Cape parrot & Poicephalus robustus & E Visitor \\
\hline Knysna turaco & Tauraco corythaix & Resident \\
\hline red-chested cuckoo & Cuculus solitarius & Summer migrant \\
\hline black cuckoo & Cuculus clamosus & Summer migrant \\
\hline emerald cuckoo & Chrysococcyx cupreus & Summer migrant \\
\hline barn owl & Tyto alba & Visitor? \\
\hline African wood owl & Strix woodfordii & Probable resident \\
\hline Narina trogon & Apaloderma narina & Resident \\
\hline green wood-hoopoe & Phoeniculus purpureus & Probable resident \\
\hline crowned hornbill & Tockus alboterminatus & Resident \\
\hline red-fronted tinkerbird & Pogoniulus pusillus & Resident \\
\hline scaly-throated honeyguide & Indicator variegatus & Probable resident \\
\hline Knysna woodpecker & Campethera notata & E Resident \\
\hline olive woodpecker & Dendropicos griseocephalus & Resident \\
\hline grey cuckooshrike & Coracina caesia & Resident \\
\hline black-headed oriole & Oriolus larvatus & Resident \\
\hline bush blackcap & Lioptilus nigricapillus & E Possible resident \\
\hline terrestrial brownbul & Phyllastrephus terrestris & Resident \\
\hline sombre greenbul & Andropadus importunus & Resident \\
\hline olive thrush & Turdus olivaceus & Resident \\
\hline chorister robin-chat & Cossypha dichroa & E Resident \\
\hline brown scrub-robin & Cercotrichas signata & E Probable resident \\
\hline white-starred robin & Pogonocichla stellata & Probable resident \\
\hline bar-throated apalis & Apalis thoracica & Resident \\
\hline yellow-breasted apalis & Apalis flavida & Resident \\
\hline green-backed camaroptera & Camaroptera brachyura & Resident \\
\hline Barratt's warbler & Bradypterus barratti & E Resident \\
\hline yellow-throated woodland warbler & Phylloscopus ruficapilla & Resident \\
\hline African dusky flycatcher & Muscicapa adusta & Resident \\
\hline Cape batis & Batis capensis & E Resident \\
\hline blue-mantled crested-flycatcher & Trochocercus cyanomelas & Resident \\
\hline African paradise-flycatcher & Terpsiphone viridis & Summer migrant \\
\hline mountain wagtail & Motacilla clara & Probable resident \\
\hline southern boubou & Laniarius ferrugineus & E Resident \\
\hline black-backed puffback & Dryoscopus cubla & Resident \\
\hline olive bush-shrike & Chlorophoneus olivaceus & Resident \\
\hline orange-breasted bush-shrike & Chlorophoneus sulfureopectus & Visitor \\
\hline red-winged starling & Onychognathus morio & Resident \\
\hline southern double-collared sunbird & Cinnyris chalybeus & E Resident \\
\hline grey sunbird & Cyanomitra veroxii & Resident \\
\hline collared sunbird & Anthodiaeta collaris & Resident \\
\hline Cape white-eye & Zosterops virens & E Resident \\
\hline
\end{tabular}


Table 2: (continued)

\begin{tabular}{lll}
\hline Common name & Scientific name & Status in reserve \\
\hline dark-backed weaver & Ploceus bicolor & Resident \\
forest canary & Crithagra scotops & E Resident \\
\hline
\end{tabular}

Based on current distribution data in "Roberts VII" (Hockey et al. 2005), 66 species could occur in montane forests along the Amathole Mountain chain, and of this total, 56 have been recorded at Fort Fordyce to date. This is a significant proportion of the South African forest avifauna. Symes et al. (2002) found no significant seasonal variation in forest-specific or forestendemic and near-endemic species during their surveys; 27 of their 33 "forest-specific" species were recorded at Fort Fordyce and none of these showed any seasonal pattern in occurrence.

\section{Seasonal occurence}

How effective are visits spread over different months in different years at detecting patterns of seasonal occurrence? This can best be assessed by examining the records of known migrants in our database. Whereas the jackal buzzard (Buteo rufofuscus) has been seen in every month of the year, the steppe buzzard (Buteo vulpinus) has been recorded only from October to February. Four cuckoo species (African emerald Chrysococcyx cupreus, black Cuculus clamosus, Klaas's Chrysococcyx klaas, and red-chested cuckoo Cuculus solitarius) have all been recorded for each of the months October to February; only Klaas's cuckoo has been recorded at other times (March and April), and this species is known to overwinter in small numbers. The black saw-wing (Psalidoprocne pristoptera) and white-rumped swift (Apus caffer) have both been recorded in every month from September to March, with no records from April to August. A similar pattern is found in the three swallow species (barn Hirundo rustica, greater striped Cecropis cucullata and lesser striped swallows Cecropis abyssinica), with no winter records for any of them. This suggests that our sampling should be adequate to detect presence/absence of most species. What can we deduce about the forest birds as listed in Table 2?

Apart from the cuckoos mentioned above, only one of these forest species, the African paradise flycatcher (Terpsiphone viridis) (Figure 3), is primarily migratory in our area, and the records seem to reflect this with no reports from May to August - whereas the blue-mantled crested-flycatcher (Trochocercus cyanomelas) has been seen in every month of the year. For some species, however, we currently have too few records to draw any conclusions; these are discussed briefly below.

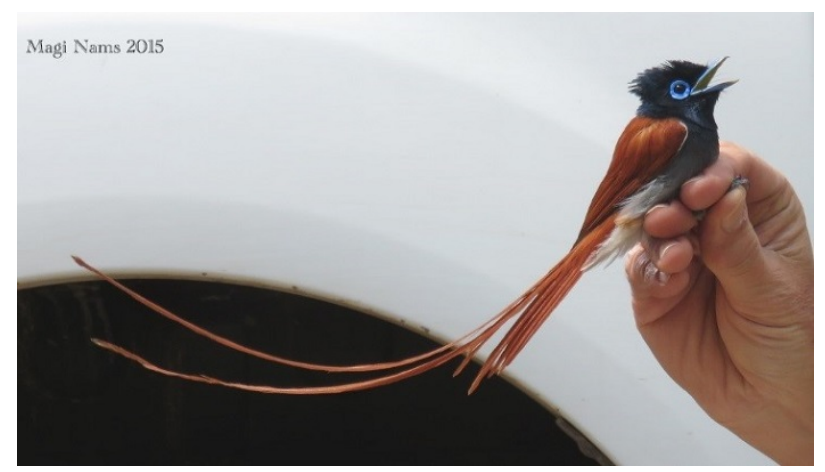

Figure 3: Male African paradise flycatcher (Photo Magi Nams)

There are $<5$ records for the rufous-breasted sparrowhawk (Accipiter rufiventris), buff-spotted flufftail (Sarothrura elegans), Cape parrot, barn owl (Tyto alba), African wood owl (Strix wood- 
fordii), tambourine dove (Turtur tympanistria), green wood-hoopoe (Phoeniculus purpureus), scalythroated honeyguide (Indicator variegatus), bush blackcap (Figure 4), brown scrub-robin (Cercotrichas signata), mountain wagtail (Motacilla clara) and orange-breasted bush-shrike (Telophorus sulfureopectus).

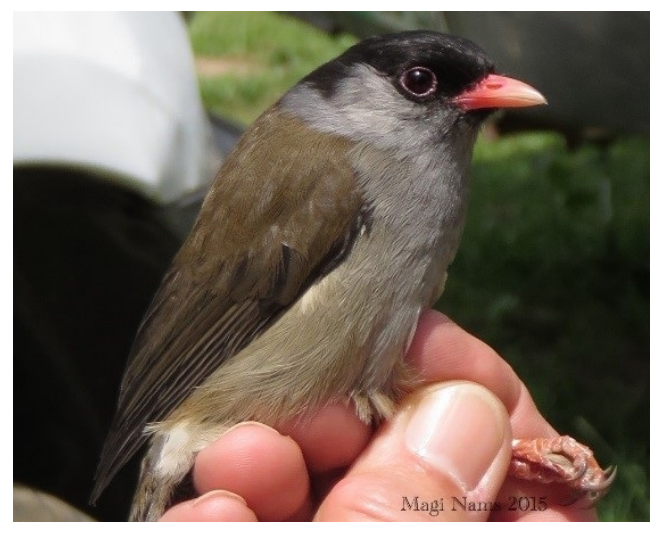

Figure 4: Bush blackcap (Photo Magi Nams)

Of these species, we would speculate that the African wood owl, scaly-throated honeyguide, bush blackcap, brown scrub-robin and mountain wagtail could be rare residents within the reserve; the others are probably occasional visitors, and may be more common in the valleys below. With both summer and winter records for the forest buzzard (Buteo trizonatus), African goshawk (Accipiter tachiro) and African harrier-hawk (Polyboroides typus), they could be rare residents or merely irregular visitors.

For most of the other species, we have at least 15 records, while the southern boubou ( $\mathrm{La}$ niarius ferrugineus) and sombre greenbul (Andropadus importunus) have been recorded on every visit. Vernon (1989) discussed forest birds in the East London region, and mentioned six species with regular altitudinal movements between inland forests and the coast: grey cuckooshrike (Coracina caesia), bush blackcap, Cape robin-chat (Cossypha caffra), white-starred robin (Pogonocichla stellata) (Figure 5), Barratt's warbler and yellow-throated warbler (Setophaga dominica) (Figure 6).

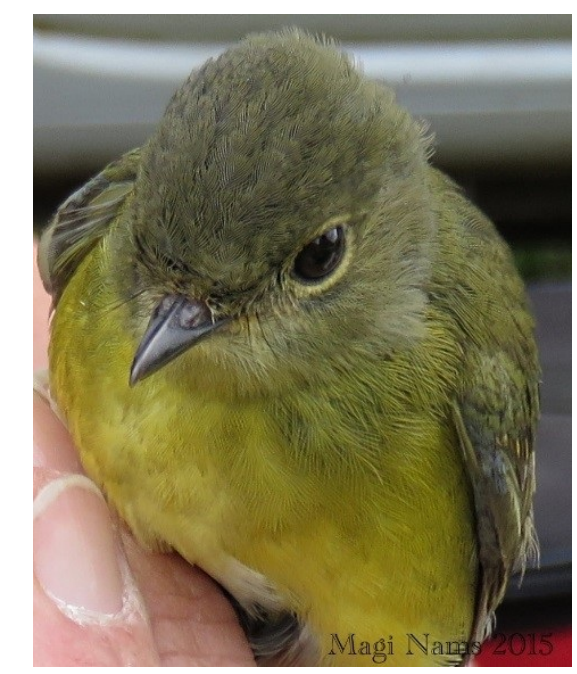

Figure 5: Immature white-starred robin (Photo Magi Nams) 


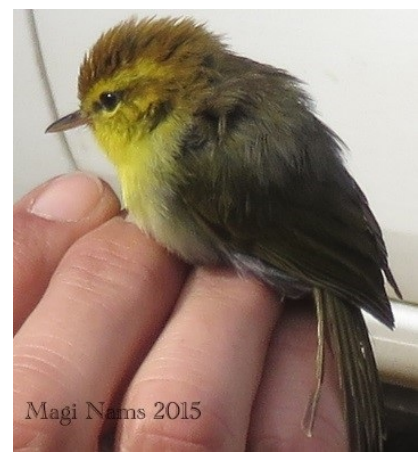

Figure 6: Yellow-throated warbler (Photo Magi Nams)

The question of altitudinal movements has been discussed in more detail elsewhere (Craig and Hulley in press); it will be summarised briefly here. There is a winter record of bush blackcaps from Grahamstown (Craig 1986), while Vernon (1989) noted that a high proportion of his observations of grey cuckooshrike, Cape robin-chat, Barratt's warbler and yellow-throated warbler at the coast were from the months Apr-Sept. Thus it is surprising that at Fort Fordyce all our records of Barratt's warbler are from this period (Apr-Sept), with no summer records to date. Vernon (1989), however, commented that in some years birds may not leave the montane forest, and for the white-starred robin, studies elsewhere have suggested that only a part of the population undertakes regular altitudinal movements (Oatley 1982, Dowsett 1985). At Fort Fordyce, we have recorded grey cuckooshrike, Cape robin-chat and yellow-throated warbler throughout the year, while for white-starred robin there are records for 10 months (Appendix 1). Chorister robin-chats (Cossypha dichroa) have been recorded in every month; Vernon (1989) categorised this species as resident, although Johnson and Maclean (1994) listed it among altitudinal migrants in KwaZulu-Natal. A chorister robin-chat ringed in July at Fort Fordyce was caught again in July the following year, confirming that some birds do stay through the winter.

\section{Ringing}

During visits up to 1997, 65 birds of 21 species were ringed. Since 2007 we have ringed 510 birds of 56 species (Appendix 2), thus capturing 32\% of the species recorded, and $59 \%$ of the forest specialists (as listed by Symes et al. 2002, Brown 2006). We have recaptured 50 individuals (almost $10 \%$ of the ringed birds) from 17 species, with the oldest records an olive thrush (Turdus olivaceus) and a black-backed puffback (Dryoscopus cubla), both eight years after ringing. A green-backed camaroptera (Camaroptera brachyura), yellow-throated warbler, southern double-collared sunbird (Cinnyris chalybeus) and Cape white-eye (Zosterops virens) have been recaptured after more than six years, and a white-starred robin after four years. Few birds have been handled more than twice (Table 3); apart from the white-starred robin, these are all species for which our observations indicate that some birds, if not the same individuals, are present throughout the year (cf. Appendix 1). It is interesting to compare our ringing results with those of other ringers operating in forest sites in South Africa.

Also in Afromontane forest, Symes et al. (2002) ringed 403 birds at two inland forest reserves (Hlabeni and Ngele) in KwaZulu-Natal, capturing about 35\% of all the species observed there, but $>50 \%$ of the forest-specific species. This paper provided no further details on the individual species ringed, nor information on recaptures. In a coastal forest reserve (Umdoni Park) in KwaZulu-Natal, Brown (2006) ringed 466 individual birds of 44 species, which comprised only $23 \%$ of the species recorded at this site, but again $>50 \%$ of the forest-specific species. Over a five-year period, Brown (2006) recaptured $8.6 \%$ of the birds ringed. His most-ringed species by far were bronze mannikin (Lonchura cucullata) and red-backed mannikin (Lonchura nigriceps) (neither of which occur at Fort Fordyce), followed by red-capped robin-chat and olive sunbird 
Table 3: Ringed birds captured more than twice at Fort Fordyce

\begin{tabular}{lll}
\hline Species & Date ringed & Dates recaptured \\
\hline black-backed puffback & Sept 2007 & Apr 2008, Oct 2015 \\
olive thrush & Dec 2014 & Oct 2015, Jul, Oct 2017 \\
chorister robin-chat & Feb 2015 & Oct, Nov 2015 \\
white-starred robin & Nov 2010 & Oct 2011, Sept 2013, Oct 2014 \\
green-backed camaroptera & Oct 2007 & Apr, Jun 2008, Apr 2010 \\
green-backed camaroptera & Sept 2009 & Nov 2014, Nov 2015 \\
Cape white-eye & Sept 2007 & Apr 2010, Nov 2016 \\
Cape white-eye & Apr 2010 & Nov 2010, Oct 2011 \\
Cape white-eye & Feb 2012 & May 2012, Oct 2014 \\
yellow-throated warbler & Oct 2007 & Dec 2007, Dec 2008, Sept 2013 \\
southern double-collared sunbird & Sept 2007 & Oct 2011, Feb 2012 \\
southern double-collared sunbird & May 2011 & July 2015, July 2017 \\
\hline
\end{tabular}

(Cynomitra olivacea) (both restricted to coastal forests in the Eastern Cape), brown scrub-robin and green-backed camaroptera.

Williams (2016) described an eleven-year ringing study in an Afromontane forest patch on the Drakensberg escarpment in Mpumalanga. At this site, 384 birds of 43 species were ringed, and 53 individuals of 10 species recaptured. The most frequently ringed species were Cape robin-chat, black-backed puffback, Knysna turaco (Tauraco corythaix), chorister robin-chat, Cape batis (Batis capensis), green-backed camaroptera, blue-mantled crested flycatcher and terrestrial brownbul (Phyllastrephus terrestris) (all $>20$ individuals).

All of these species (except the blue-mantled crested flycatcher) have been captured at Fort Fordyce, and all were found to be present throughout the year. However, whereas Williams (2016) captured only 9 sunbirds of five species, at Fort Fordyce the southern double-collared sunbird was one of our most-ringed birds ( $>40$ individuals). We also caught far more sombre greenbuls than terrestrial brownbuls (see Appendix 2), the reverse of Williams (2016) capture rates; this could be influenced by net positioning at the two sites.

\section{Conclusions}

A significant proportion of the regional forest avifauna is found within the Fort Fordyce reserve, and some individuals of all species appear to be present throughout the year. Ringing to date has produced no evidence of movement between this protected area and other localities. While we currently lack good information on breeding status, and breeding success, of these forest species, it is clear that this reserve constitutes a valuable conservation area for forest birds in the Eastern Cape.

\section{Acknowledgements}

We are grateful to Eastern Cape Parks for permission to survey and ring birds at Fort Fordyce. The park managers have always been helpful, and interested in our findings. Travel costs have been covered by research grants from Rhodes University and the National Research Foundation. Many birdclub members, students, and other volunteers have assisted with the surveys and ringing, in particular Daniel Danckwerts, Mark Galpin, Mary Hulley, Isabel Micklem, the late John Moore, Lorraine Mullins, Carlota Fernandez Muniz, Gareth Nuttall-Smith, Diane Smith, Kate Webster, and Milena Wolmarans. Special thanks to Magi Nams for the use of her photographs, taken during two ringing sessions in 2015. 


\section{References}

Brown, M 2006. Annual and seasonal trends in aivifaunal species richness in a coastal lowlands forest reserve in South Africa. Ostrich 77:58-66.

Craig A 1986. Forest birds on Rhodes University campus. Diaz Diary 155:4-5.

Craig A 2007. Bird research at Fort Fordyce. Diaz Diary 35(4):13-15.

Craig A 2012. Bird research at Fort Fordyce. Bee-eater 63(3):51-54.

Craig AJFK and Hulley PE In press. Montane forest birds in winter: do they regularly move to lower altitudes? Observations from the Eastern Cape. Ostrich.

Dowsett RJ 1985. Site-fidelity and survival rates of some montane forest birds in Malawi, south-central Africa. Biotropica 17:145-154.

Harrison JA, Allan DG, Underhill LG, Herremans M, Tree AJ and Parker V (eds) 1997. The atlas of Southern African birds, vol. 1. BirdLife South Africa, Johannesburg.

Hockey PAR, Dean WRJ and Ryan PG (eds) 2005. Roberts birds of southern Africa. 7th edn. The Trustees of the John Voelcker Bird Book Fund, Cape Town.

Johnson DN and Maclean GL 1994. Altitudinal migration in Natal. Ostrich 65:86-94.

Marnewick MD, Retief EF, Theron NT, Wright DR and Anderson TA 2015. Important Bird and Biodiversity Areas of South Africa. Johannesburg: BirdLife South Africa.

Oatley TB 1982. The Starred Robin in Natal. Part 2: Annual cycles and feeding ecology. Ostrich 53:193-205.

Rutherford MC and Westfall RH 1986. Biomes of southern Africa - an objective categorization. Memoirs of the Botanical Survey of South Africa 54:1-98.

Skead CJ 1967. Ecology of birds in the Eastern Cape Province. Ostrich supplement 7:1-103.

Symes CT, Wirminghaus JO and Downs CT 2002. Species richness and seasonality of forest avifauna in three South African Afromontane forests. Ostrich 73:106-113.

Taylor MR, Peacock F and Wanless RM (eds) 2015. The Eskom Red Data book of birds of South Africa, Lesotho and Swaziland. BirdLife South Africa, Johannesburg.

Vernon CJ 1989. Observations on the forest birds around East London. Ostrich supplement 14:75-84.

Williams DM 2016. Bird population trends in a patch of temperate forest on the Drakensberg escarpment, Mpumalanga. Biodiversity Observations 7.6:1-4. http://bo.adu.org.za/ content.php?id=199 


\section{Appendices}

Appendix 1: Observations (sight and sound) of birds at Fort Fordyce; own records and SABAP2 data

\begin{tabular}{|c|c|c|c|c|}
\hline \multirow[b]{2}{*}{ Common name } & \multirow[b]{2}{*}{ Scientific name } & \multirow[b]{2}{*}{ Records } & \multicolumn{2}{|c|}{ Months (min 12 records) } \\
\hline & & & Present & Not recorded \\
\hline apalis, bar-throated & Apalis thoracica & 48 & $1-12$ & \\
\hline apalis, yellow-breasted & Apalis flavida & 21 & $1-3,5-12$ & 4 \\
\hline barbet, black-collared & Lybius torquatus & 3 & & \\
\hline batis, Cape & Batis capensis & 53 & $1-12$ & \\
\hline batis, chinspot & Batis molitor & 2 & & \\
\hline bishop, yellow & Euplectes capensis & 21 & $2,5-10,12$ & $1,3,4,11$ \\
\hline blackcap, bush & Lioptilus nigricapillus & 2 & & \\
\hline bokmakierie & Telophorus zeylonus & 5 & & \\
\hline boubou, southern & Laniarius ferrugineus & 59 & $1-12$ & \\
\hline brownbul, terrestrial & Phyllastrephus terrestris & 39 & $1-12$ & \\
\hline bulbul, dark-capped & Pycnonotus tricolor & 54 & $1-12$ & \\
\hline bush-shrike, orange-breasted & Chlorophoneus sulphureopectus & 1 & & \\
\hline bush-shrike, olive & Chlorophoneus olivaceus & 32 & $1-12$ & \\
\hline buzzard, forest & Buteo trizonatus & 6 & & \\
\hline buzzard, jackal & Buteo rufofuscus & 28 & $1-12$ & \\
\hline buzzard, steppe & Buteo vulpinus & 18 & $1,2,10-12$ & $3-9$ \\
\hline camaroptera, green-backed & Camaroptera brachyura & 49 & $1-12$ & \\
\hline canary, brimstone & Crithagra sulphuratus & 12 & $2,6,7,9-12$ & $1,3-5,8$ \\
\hline canary, Cape & Serinus canicollis & 43 & $1,2,4-12$ & 3 \\
\hline canary, forest & Crithagra scotops & 50 & $1-12$ & \\
\hline canary, yellow-fronted & Crithagra mozambicus & 25 & $2-12$ & 1 \\
\hline chat, familiar & Cercolmela familiaris & 3 & & \\
\hline cisticola, grey-backed & Cisticola subruficapilla & 2 & & \\
\hline cisticola, lazy & Cisticola aberrans & 41 & $1-12$ & \\
\hline cisticola, Levaillant's & Cisticola tinniens & 8 & & \\
\hline cisticola, wailing & Cisticola lais & 12 & $2,4,7,9-12$ & $1,3,5,6,8$ \\
\hline cliff-chat, mocking & Thamnolaea cinnamomeiventris & 1 & & \\
\hline cormorant, reed & Phalacrocorax africanus & 2 & & \\
\hline cormorant, white-breasted & Phalacrocorax carbo & 1 & & \\
\hline coucal, Burchell's & Centropus burchelli & 1 & & \\
\hline crane, blue & Anthropoides paradiseus & 3 & & \\
\hline crested-flycatcher, blue-mantled & Trochocercus cyanomelas & 27 & $1-12$ & \\
\hline crombec, long-billed & Sylvietta rufescens & 1 & & \\
\hline crow, Cape & Corvus capensis & 54 & $1-12$ & \\
\hline crow, Pied & Corvus albus & 4 & & \\
\hline cuckoo, African emerald & Chrysococcyx cupreus & 11 & $1,2,10-12$ & $3-9$ \\
\hline cuckoo, black & Cuculus clamosus & 17 & $1,2,10-12$ & $3-9$ \\
\hline cuckoo, diderick & Chrysococcyx caprius & 2 & & \\
\hline cuckoo, Klaas's & Chrysococcyx klaas & 16 & $1,3,4,10-12$ & $2,5-9$ \\
\hline cuckoo, red-chested & Cuculus solitarius & 17 & $1,2,10-12$ & $3-9$ \\
\hline cuckoo-shrike, black & Campephaga flava & 2 & & \\
\hline cuckoo-shrike, grey & Coracina caesia & 22 & $1,2,4-12$ & 3 \\
\hline dove, laughing & Streptopelia senegalensis & 2 & & \\
\hline dove, lemon & Aplopelia larvata & 13 & $1-12$ & \\
\hline dove, red-eyed & Streptopelia semitorquata & 33 & $1-12$ & \\
\hline dove, rock & Columba livia & 1 & & \\
\hline dove, tambourine & Turtur tympanistria & 4 & & \\
\hline drongo, fork-tailed & Dicrurus adsimilis & 35 & $1-12$ & \\
\hline
\end{tabular}


(Appendix 1 continued)

\begin{tabular}{|c|c|c|c|c|}
\hline \multirow[b]{2}{*}{ Common name } & \multirow[b]{2}{*}{ Scientific name } & \multirow[b]{2}{*}{ Records } & \multicolumn{2}{|c|}{ Months (min 12 records) } \\
\hline & & & Present & Not recorded \\
\hline duck, yellow-billed & Anas undulata & 2 & & \\
\hline eagle, African crowned & Stephanoaetus coronatus & 19 & $1,2,4-9,11,12$ & 3,10 \\
\hline eagle, booted & Aquila pennatus & 6 & & \\
\hline eagle, long-crested & Lophaetus occipitalis & 19 & $2-8,10-12$ & 1,9 \\
\hline eagle, Verreaux's & Aquila verreauxii & 2 & & \\
\hline falcon, lanner & Falco biarmicus & 3 & & \\
\hline falcon, peregrine & Falco peregrinus & 1 & & \\
\hline firefinch, African & Lagonosticta rubricata & 15 & $1-6,8-10,12$ & 7,11 \\
\hline fiscal, common & Lanius collaris & 37 & $2-12$ & 1 \\
\hline flufftail, buff-spotted & Sarothrura elegans & 1 & & \\
\hline flufftail, striped & Sarothrura affinis & 3 & & \\
\hline flycatcher, African dusky & Muscicapa adusta & 38 & $1-4,7-12$ & 5,6 \\
\hline flycatcher, fiscal & Sigelus silens & 1 & & \\
\hline flycatcher, spotted & Muscicapa striata & 2 & & \\
\hline francolin, grey-winged & Scleroptila afra & 2 & & \\
\hline goose, Egyptian & Alopochen aegyptiacus & 2 & & \\
\hline goshawk, African & Accipiter tachiro & 8 & & \\
\hline goshawk, gabar & Melierax gabar & 2 & & \\
\hline goshawk, southern pale chanting & Melierax canorus & 1 & & \\
\hline grassbird, Cape & Sphenoeacus afer & 13 & $2,3,5,8-10,12$ & $1,4,6,7,11$ \\
\hline greenbul, sombre & Andropadus importunus & 59 & $1-12$ & \\
\hline guineafowl, helmeted & Numida meleagris & 3 & & \\
\hline hamerkop & Scopus umbretta & 1 & & \\
\hline harrier, black & Circus maurus & 1 & & \\
\hline harrier-hawk, African & Polyboroides typus & 12 & $1,2,4,8,9,12$ & $3,5-7,10,12$ \\
\hline heron, black-headed & Ardea melanocephala & 2 & & \\
\hline heron, grey & Ardea cinerea & 1 & & \\
\hline honeybird, brown-backed & Prodotiscus regulus & 1 & & \\
\hline honeyguide, greater & Indicator indicator & 1 & & \\
\hline honeyguide, lesser & Indicator minor & 5 & & \\
\hline honeyguide, scaly-throated & Indicator variegatus & 1 & & \\
\hline hoopoe, African & Upupa africana & 3 & & \\
\hline hornbill, crowned & Tockus alboterminatus & 16 & 3-11 & $1,2,12$ \\
\hline house-martin, common & Delichon urbicum & 2 & & \\
\hline ibis, African sacred & Threskiornis aethiopicus & 1 & & \\
\hline ibis, hadeda & Bostrychia hagedash & 38 & $1-5,7-12$ & 6 \\
\hline indigobird, dusky & Vidua funerea & 2 & & \\
\hline kestrel, rock & Falco rupicolus & 1 & & \\
\hline kingfisher, brown-hooded & Halcyon albiventris & 1 & & \\
\hline kite, black-shouldered & Elanus caeruleus & 6 & & \\
\hline kite, yellow-billed & Milvus aegyptius & 1 & & \\
\hline lapwing, black-winged & Vanellus melanopterus & 1 & & \\
\hline lapwing, blacksmith & Vanellus armatus & 1 & & \\
\hline lapwing, crowned & Vanellus coronatus & 1 & & \\
\hline longclaw, Cape & Macronyx capensis & 8 & & \\
\hline martin, rock & Hirundo fuligula & 12 & $2,6,9-12$ & $1,3-5,7,8$ \\
\hline moorhen, common & Gallinula chloropus & 2 & & \\
\hline mousebird, red-faced & Urocolius indicus & 7 & & \\
\hline mousebird, speckled & Colius striatus & 32 & $1-12$ & \\
\hline neddicky & Cisticola fulvicapilla & 16 & $1-3,6-12$ & 4,5 \\
\hline nightjar, fiery-necked & Caprimulgus rufigena & 1 & & \\
\hline olive-pigeon, African & Columba arquatrix & 32 & $1-12$ & \\
\hline
\end{tabular}


(Appendix 1 continued)

\begin{tabular}{|c|c|c|c|c|}
\hline \multirow[b]{2}{*}{ Common name } & \multirow[b]{2}{*}{ Scientific name } & \multirow[b]{2}{*}{ Records } & \multicolumn{2}{|c|}{ Months (min 12 records) } \\
\hline & & & Present & Not recorded \\
\hline oriole, black-headed & Oriolus larvatus & 51 & $1-12$ & \\
\hline owl, barn & Tyto alba & 1 & & \\
\hline paradise-flycatcher, African & Terpsiphone viridis & 13 & $1,4,9-12$ & $2,3,5-8$ \\
\hline parrot, Cape & Poicephalus robustus & 1 & & \\
\hline petronia, yellow-throated & Petronia superciliaris & 2 & & \\
\hline pigeon, speckled & Columba guinea & 4 & & \\
\hline pipit, African & Anthus cinnamomeus & 10 & & \\
\hline pipit, plain-backed & Anthus leucophrys & 2 & & \\
\hline prinia, Karoo & Prinia maculosa & 30 & $1-12$ & \\
\hline prinia, tawny-flanked & Prinia subflava & 5 & & \\
\hline puffback, black-backed & Dryoscopus cubla & 55 & $1-12$ & \\
\hline quail, common & Coturnix coturnix & 2 & & \\
\hline raven, white-necked & Corvus albicollis & 19 & $1-5,7-12$ & 6 \\
\hline robin, white-starred & Pogonocichla stellata & 21 & 3-12 & 1,2 \\
\hline robin-chat, Cape & Cossypha caffra & 48 & $1-12$ & \\
\hline robin-chat, chorister & Cossypha dichroa & 40 & $1-12$ & \\
\hline rock-thrush, Cape & Monticola rupestris & 1 & & \\
\hline saw-wing, black & Psalidoprocne holomelaena & 18 & $1-3,9-12$ & $4-8$ \\
\hline scrub-robin, brown & Cercotrichas signata & 2 & & \\
\hline scrub-robin, white-browed & Cercotrichas leucophrys & 2 & & \\
\hline secretarybird & Sagittarius serpentarius & 4 & & \\
\hline seedeater, streaky-headed & Crithagra gularis & 5 & & \\
\hline shrike, red-backed & Lanius collurio & 3 & & \\
\hline sparrowhawk, rufous-breasted & Accipiter rufiventris & 1 & & \\
\hline spurfowl, red-necked & Pternistis afer & 40 & $1-12$ & \\
\hline starling, Cape glossy & Lamprotornis nitens & 12 & $4,7,8,11,12$ & $1-3,5,6,9,10$ \\
\hline starling, common & Sturnus vulgaris & 2 & & \\
\hline starling, pied & Lamprotornis bicolor & 1 & & \\
\hline starling, red-winged & Onychognathus morio & 55 & $1-12$ & \\
\hline stonechat, African & Saxicola torquatus & 32 & $2-12$ & 1 \\
\hline stork, white & Ciconia ciconia & 1 & & \\
\hline sunbird, amethyst & Chalcomitra amethystina & 31 & $1-5,7-12$ & 6 \\
\hline sunbird, collared & Hedydipna collaris & 31 & $1-12$ & \\
\hline sunbird, greater double-collared & Cinnyris afer & 30 & $1-12$ & \\
\hline sunbird, grey & Cyanomitra veroxii & 17 & $1,5,7-12$ & $2-4,6$ \\
\hline sunbird, malachite & Nectarinia famosa & 6 & & \\
\hline sunbird, southern double-collared & Cinnyris chalybeus & 45 & $1-12$ & \\
\hline swallow, barn & Hirundo rustica & 13 & $1-3,10-12$ & $4-9$ \\
\hline swallow, greater striped & Hirundo cucullata & 15 & $1-4,9,11,12$ & $5-8,10$ \\
\hline swallow, lesser striped & Hirundo abyssinica & 24 & $1-3,9-12$ & $4-8$ \\
\hline swallow, white-throated & Hirundo albigularis & 6 & & \\
\hline swift, African black & Apus barbatus & 13 & $2,3,7,9-12$ & $1,4-6,8$ \\
\hline swift, alpine & Tachymarptis melba & 8 & & \\
\hline swift, horus & Apus horus & 1 & & \\
\hline swift, little & Apus affinis & 3 & & \\
\hline swift, white-rumped & Apus caffer & 18 & $1-3,9-12$ & $4-8$ \\
\hline tchagra, southern & Tchagra tchagra & 13 & $2,3,5-12$ & 1,4 \\
\hline thick-knee, spotted & Burhinus capensis & 4 & & \\
\hline thrush, olive & Turdus olivaceus & 39 & $1-12$ & \\
\hline tinkerbird, red-fronted & Pogoniulus pusillus & 32 & $1-12$ & \\
\hline tit, southern black & Parus niger & 17 & $1-3,5-11$ & 4,12 \\
\hline trogon, Narina & Apaloderma narina & 13 & $6,7,9-12$ & $1-5,8$ \\
\hline
\end{tabular}


(Appendix 1 continued)

\begin{tabular}{|c|c|c|c|c|}
\hline \multirow[b]{2}{*}{ Common name } & \multirow[b]{2}{*}{ Scientific name } & \multirow[b]{2}{*}{ Records } & \multicolumn{2}{|c|}{ Months (min 12 records) } \\
\hline & & & Present & Not recorded \\
\hline turaco, Knysna & Tauraco corythaix & 46 & $1-12$ & \\
\hline turtle-dove, Cape & Streptopelia capicola & 30 & $1-12$ & \\
\hline wagtail, Cape & Motacilla capensis & 41 & $2-12$ & 1 \\
\hline wagtail, mountain & Motacilla clara & 2 & & \\
\hline warbler, Barratt's & Bradypterus barratti & 20 & $4-10$ & $1-3,11,12$ \\
\hline warbler, willow & Phylloscopus trochilus & 3 & & \\
\hline waxbill, common & Estrilda astrild & 9 & & \\
\hline waxbill, swee & Coccopygia melanotis & 19 & $1-4,6,9-12$ & $5,7,8$ \\
\hline weaver, Cape & Ploceus capensis & 4 & & \\
\hline weaver, dark-backed & Ploceus bicolor & 35 & $1-12$ & \\
\hline weaver, spectacled & Ploceus ocularis & 1 & & \\
\hline weaver, thick-billed & Amblyospiza albifrons & 2 & & \\
\hline weaver, village & Ploceus cucullatus & 1 & & \\
\hline white-eye, Cape & Zosterops virens & 56 & $1-12$ & \\
\hline whydah, pin-tailed & Vidua macroura & 3 & & \\
\hline widowbird, red-collared & Euplectes ardens & 1 & & \\
\hline wood-dove, emerald-spotted & Turtur chalcospilos & 7 & & \\
\hline wood-hoopoe, green & Phoeniculus purpureus & 3 & & \\
\hline wood-owl, African & Strix woodfordii & 3 & & \\
\hline warbler, yellow-throated & Phylloscopus ruficapilla & 32 & $2-12$ & 1 \\
\hline woodpecker, cardinal & Dectropicos fuscescens & 1 & & \\
\hline woodpecker, Knysna & Campethera notata & 29 & & \\
\hline woodpecker, olive & Dendropicos griseocephalus & 25 & $1-10,12$ & 11 \\
\hline
\end{tabular}


Appendix 2: Records of birds ringed at Fort Fordyce

\begin{tabular}{|c|c|c|c|c|c|}
\hline Common name & 1988-1997 & 2007-2017 & Total & Recaptures & $\begin{array}{l}\text { Max. time } \\
\text { since ringing }\end{array}$ \\
\hline apalis, bar-throated & & 9 & 9 & & \\
\hline batis, Cape & 3 & 14 & 17 & & \\
\hline bishop, yellow & 5 & 37 & 42 & 5 & 23 months \\
\hline blackcap, bush & & 1 & 1 & & \\
\hline boubou, southern & 3 & 11 & 14 & 1 & 3 months \\
\hline brownbul, terrestrial & & 3 & 3 & 1 & 33 months \\
\hline bulbul, dark-capped & & 4 & 4 & & \\
\hline bunting, golden-breasted & 1 & & 1 & & \\
\hline bush-shrike, olive & & 3 & 3 & & \\
\hline camaroptera, green-backed & 1 & 16 & 17 & 3 & 74 months \\
\hline canary, brimstone & 2 & 1 & 3 & & \\
\hline canary, forest & 4 & 16 & 20 & 1 & 16 months \\
\hline canary, yellow-fronted & 1 & 2 & 3 & & \\
\hline cisticola, lazy & 1 & 8 & 9 & 1 & 1 month \\
\hline cuckoo, black & & 1 & 1 & & \\
\hline cuckoo, diderick & & 1 & 1 & & \\
\hline cuckoo, red-chested & & 4 & 4 & & \\
\hline cuckoo, Klaas' & & 1 & 1 & & \\
\hline dove, lemon & & 4 & 4 & & \\
\hline drongo, fork-tailed & & 1 & 1 & & \\
\hline firefinch, African & 4 & 1 & 5 & & \\
\hline fiscal, common & 1 & 1 & 2 & & \\
\hline flycatcher, African dusky & 1 & 8 & 9 & 1 & 14 months \\
\hline goshawk, African & & 2 & 2 & & \\
\hline greenbul, sombre & 2 & 33 & 35 & 4 & 14 months \\
\hline honeyguide, lesser & & 1 & 1 & & \\
\hline mousebird, speckled & 3 & 1 & 4 & & \\
\hline neddicky & & 1 & 1 & & \\
\hline oriole, black-headed & 3 & & 3 & & \\
\hline paradise-flycatcher, African & & 1 & 1 & & \\
\hline prinia, Karoo & & 2 & 2 & & \\
\hline puffback, black-backed & & 4 & 4 & 1 & 97 months \\
\hline robin, white-starred & & 8 & 8 & 2 & 48 months \\
\hline robin-chat, Cape & 1 & 12 & 13 & 5 & 25 months \\
\hline robin-chat, chorister & & 19 & 19 & 3 & 12 months \\
\hline seedeater, streaky-headed & & 2 & 2 & & \\
\hline starling, red-winged & & 4 & 4 & & \\
\hline stonechat, African & 1 & 4 & 5 & & \\
\hline sunbird, amethyst & 1 & & 1 & & \\
\hline sunbird, collared & & 6 & 6 & & \\
\hline sunbird, greater double-collared & 2 & 7 & 9 & 3 & 23 months \\
\hline sunbird, grey & & 3 & 3 & & \\
\hline sunbird, malachite & & 1 & 1 & & \\
\hline sunbird, southern double-collared & 4 & 44 & 48 & 3 & 74 months \\
\hline swallow, lesser striped & & 1 & 1 & & \\
\hline thrush, olive & 5 & 21 & 26 & 3 & 95 months \\
\hline turaco, Knysna & & 1 & 1 & & \\
\hline wagtail, Cape & & 1 & 1 & & \\
\hline wagtail, mountain & & 1 & 1 & & \\
\hline warbler, Barratt's & & 2 & 2 & & \\
\hline waxbill, swee & & 3 & 3 & & \\
\hline weaver, dark-backed & & 2 & 2 & & \\
\hline
\end{tabular}


(Appendix 2 continued)

\begin{tabular}{lrrrrl}
\hline Common name & & & & & Max. time \\
white-eye, Cape & $1988-1997$ & $2007-2017$ & Total & Recaptures & since ringing \\
warbler, yellow-throated & 16 & 173 & 189 & 15 & 79 months \\
woodpecker, Knysna & & 5 & 5 & 1 & 71 months \\
woodpecker, olive & & 3 & 3 & & \\
Totals & 65 & 1 & 1 & & \\
\hline
\end{tabular}

